Acta Crystallographica Section E

Structure Reports

Online

ISSN 1600-5368

\section{A redetermination at low temperature of the structure of triethylammonium bromide}

\author{
Natasha H. Munro and Lyall R. Hanton* \\ Department of Chemistry, University of Otago, PO Box 56, Dunedin, New Zealand \\ Correspondence e-mail: Ihanton@chemistry.otago.ac.nz
}

Received 9 October 2008; accepted 25 October 2008

Key indicators: single-crystal X-ray study; $T=90 \mathrm{~K} ;$ mean $\sigma(\mathrm{C}-\mathrm{C})=0.006 \AA$; $R$ factor $=$ $0.020 ; w R$ factor $=0.058$; data-to-parameter ratio $=24.1$.

The structure of the title compound, $\mathrm{C}_{6} \mathrm{H}_{16} \mathrm{~N}^{+} \cdot \mathrm{Br}^{-}$, was determined at low temperature and the cell dimensions were comparable to those reported for room-temperature studies [James, Cameron, Knop, Newman \& Falp, (1985). Can. J. Chem. 63, 1750-1758]. Initial analysis of the data led to the assignment of $P 3_{1} c$ as the space group rather than $P 6_{3} m c$ as reported for the room-temperature structure. Careful examination of the appropriate $\left|F_{\mathrm{o}}\right|$ values in the low-temperature data showed that the equalities $|F(\bar{h} k l)|=|F(h \bar{k} l)|$ and $|\mathrm{F}(h k l)|$ $=|F(h k \bar{l})|$ did not hold at low temperature, confirming $P 3_{1} \mathrm{c}$ as the appropriate choice of space group. As a consequence of this choice, the $\mathrm{N}$ atom sat on a threefold axis and the ethyl arms were not disordered as observed at room temperature. The crystal studied was an inversion twin with a 0.68 (3):0.32 (3) domain ratio.

\section{Related literature}

For related structures, see: James et al. (1985). For the preparation, see: Lecolley et al. (2004).

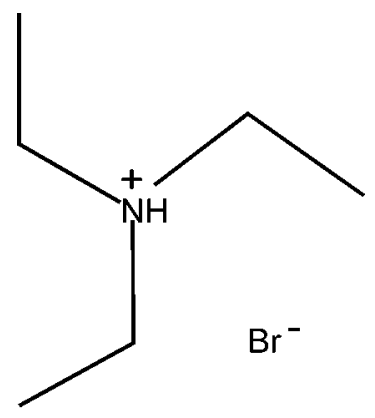

\section{Experimental}

Crystal data

$\mathrm{C}_{6} \mathrm{H}_{16} \mathrm{~N}^{+} \cdot \mathrm{Br}^{-}$

Trigonal, $P 31 c$

$a=8.3589$ (2) $\AA$

$c=7.3125(2) \AA$

$V=442.48(1) \AA^{3}$

$Z=2$

Mo $K \alpha$ radiation

$\mu=4.56 \mathrm{~mm}^{-1}$

$T=90(2) \mathrm{K}$

$0.27 \times 0.11 \times 0.10 \mathrm{~mm}$

Data collection

Bruker APEXII CCD area-detector diffractometer

Absorption correction: multi-scan (SADABS; Bruker, 2004)

$T_{\min }=0.450, T_{\max }=0.632$

Refinement

$R\left[F^{2}>2 \sigma\left(F^{2}\right)\right]=0.020$

$w R\left(F^{2}\right)=0.058$

$S=1.24$

555 reflections

23 parameters

1 restraint

8583 measured reflections 555 independent reflections 550 reflections with $I>2 \sigma(I)$ $R_{\text {int }}=0.026$

$\mathrm{H}$-atom parameters constrained

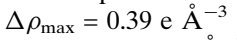

$\Delta \rho_{\min }=-0.39{\mathrm{e} \AA^{-3}}^{-3}$

Absolute structure: Flack (1983), 273 Friedel pairs

Flack parameter: 0.32 (3)

Data collection: APEX2 (Bruker, 2006); cell refinement: APEX2 and SAINT (Bruker, 2006); data reduction: $S A I N T$; program(s) used to solve structure: $S I R 97$ (Altomare et al., 1993); program(s) used to refine structure: SHELXL97 (Sheldrick, 2008); molecular graphics: SHELXTL (Sheldrick, 2008); software used to prepare material for publication: SHELXTL.

We acknowledge the award of a John Edmond Postgraduate Scholarship in Chemistry (NHM) and thank the University of Otago Research Committee and the New Economic Research Fund (grant No UOO-X0404 from the New Zealand Foundation of Research Science and Technology) for financial support.

Supplementary data and figures for this paper are available from the IUCr electronic archives (Reference: PV2113).

\title{
References
}

Altomare, A., Cascarano, G., Giacovazzo, C. \& Guagliardi, A. (1993). J. Appl. Cryst. 26, 343-350.

Bruker (2004). SADABS. Bruker AXS Inc., Madison, Wisconsin, USA.

Bruker (2006). APEX2 and SAINT. Bruker AXS Inc., Madison, Wisconsin, USA.

Flack, H. D. (1983). Acta Cryst. A39, 876-881.

James, M. A., Cameron, S. T., Knop, O., Neuman, M. \& Falk, M. (1985). Can. J. Chem. 63, 1750-1758.

Lecolley, F., Tao, L., Mantovani, G., Durkin, I., Lautru, S. \& Haddleton, D. M. (2004). Chem. Commun. pp. 2026-2027.

Sheldrick, G. M. (2008). Acta Cryst. A64, 112-122. 


\section{supporting information}

Acta Cryst. (2008). E64, o2236 [doi:10.1107/S1600536808034843]

\section{A redetermination at low temperature of the structure of triethylammonium bromide}

\section{Natasha H. Munro and Lyall R. Hanton}

\section{S1. Comment}

The title compound, (I), was isolated as a by-product in a reaction to form (2,5-oxo-1-pyrrolidyl)oxy-2-bromo-2-methylpropionate (Lecolley et al., 2004). A view of the structure of (I) is presented in Fig. 1. The crystal structures of (I) and the other halide analogues at ambient temperature have previously been described by James et al. (1985). Unlike previous work, analysis of our low-temperature data showed that (I) crystallized in the space group $\mathrm{P} 3{ }_{1} \mathrm{c}$ with the ethyl chains in fixed locations. The e.s.d.'s of the positional parameters and the $R$ factors were significantly lower than those reported for the room temperature structure. The packing of (I) (Fig. 2) at low temperature is very similar to that of the room temperature disordered structure. James et al. (1985) also analysed the IR spectra of these compounds in some detail.

\section{S2. Experimental}

The title compound, (I), was prepared as a by-product in a reaction to form (2,5-oxo-1-pyrrolidyl)oxy-2-bromo-2-methylpropionate by the method of Lecolley et al. (2004). X-Ray quality crystals were grown by the slow evaporation of an acetonitrile solution.

\section{S3. Refinement}

All $\mathrm{H}$-atoms bound to carbon were refined using a riding model with $\mathrm{d}(\mathrm{C}-\mathrm{H})=0.96 \AA, U_{\text {iso }}=1.5 U_{\text {eq }}(\mathrm{C})$ for the methyl $\mathrm{CH} \mathrm{H}$ atoms and $\mathrm{d}(\mathrm{C}-\mathrm{H})=0.97 \AA, U_{\text {iso }}=1.2 U_{\text {eq }}(\mathrm{C})$ for the methylene $\mathrm{CH} \mathrm{H}$ atoms. The H-atom bound to nitrogen was refined using a riding model with $\mathrm{d}(\mathrm{N}-\mathrm{H})=0.87 \AA, U_{\text {iso }}=1.2 U_{\text {eq }}(\mathrm{N})$. 


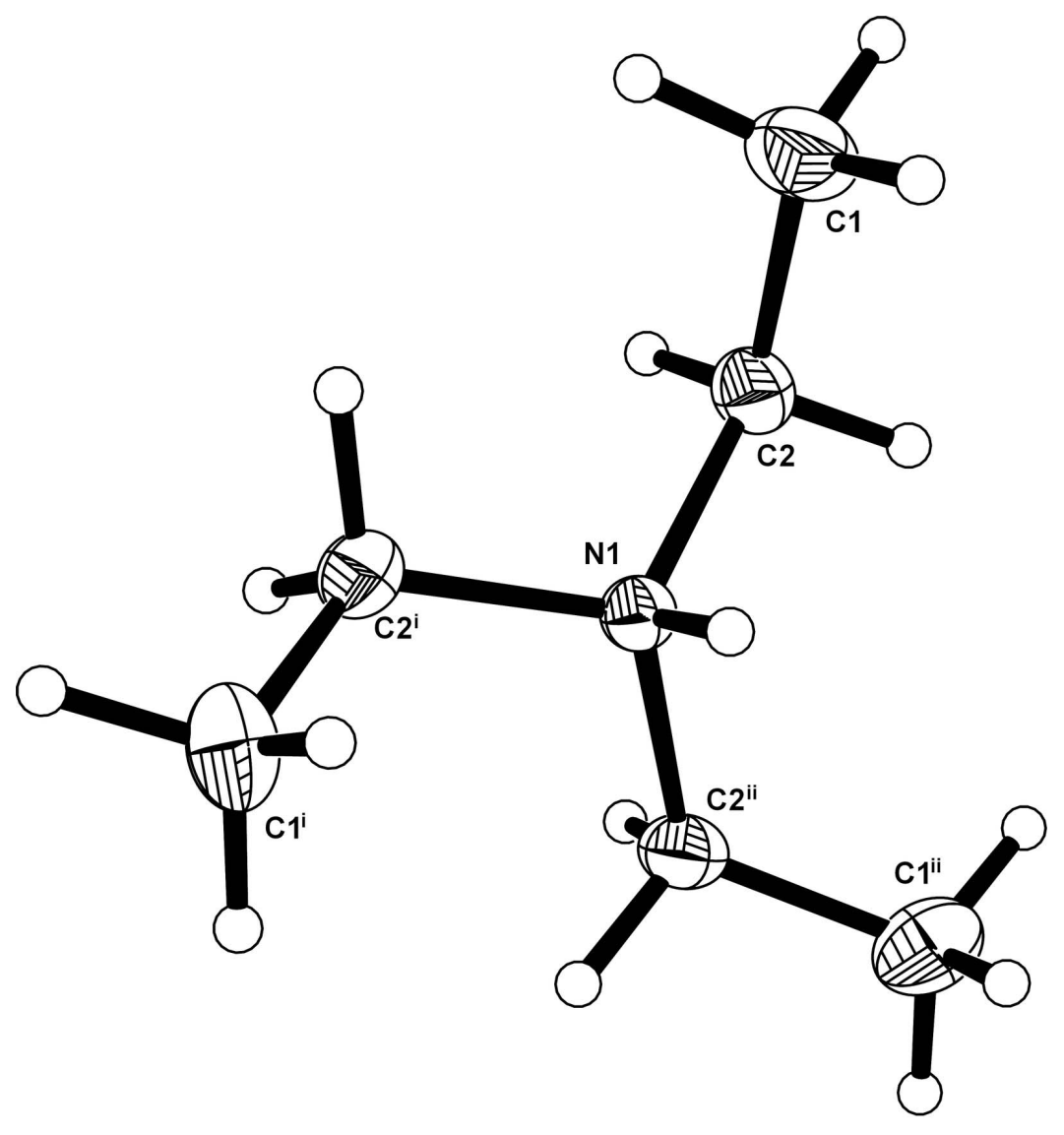

\section{Figure 1}

A view of the molecule of (I) showing the atom numbering with displacement ellipsoids drawn at the $50 \%$ probability level. Symmetry codes: (i) $-\mathrm{x}+\mathrm{y},-\mathrm{x}+1, \mathrm{z}$; (ii) $-\mathrm{y}+1, \mathrm{x}-\mathrm{y}+1, \mathrm{z}$. 


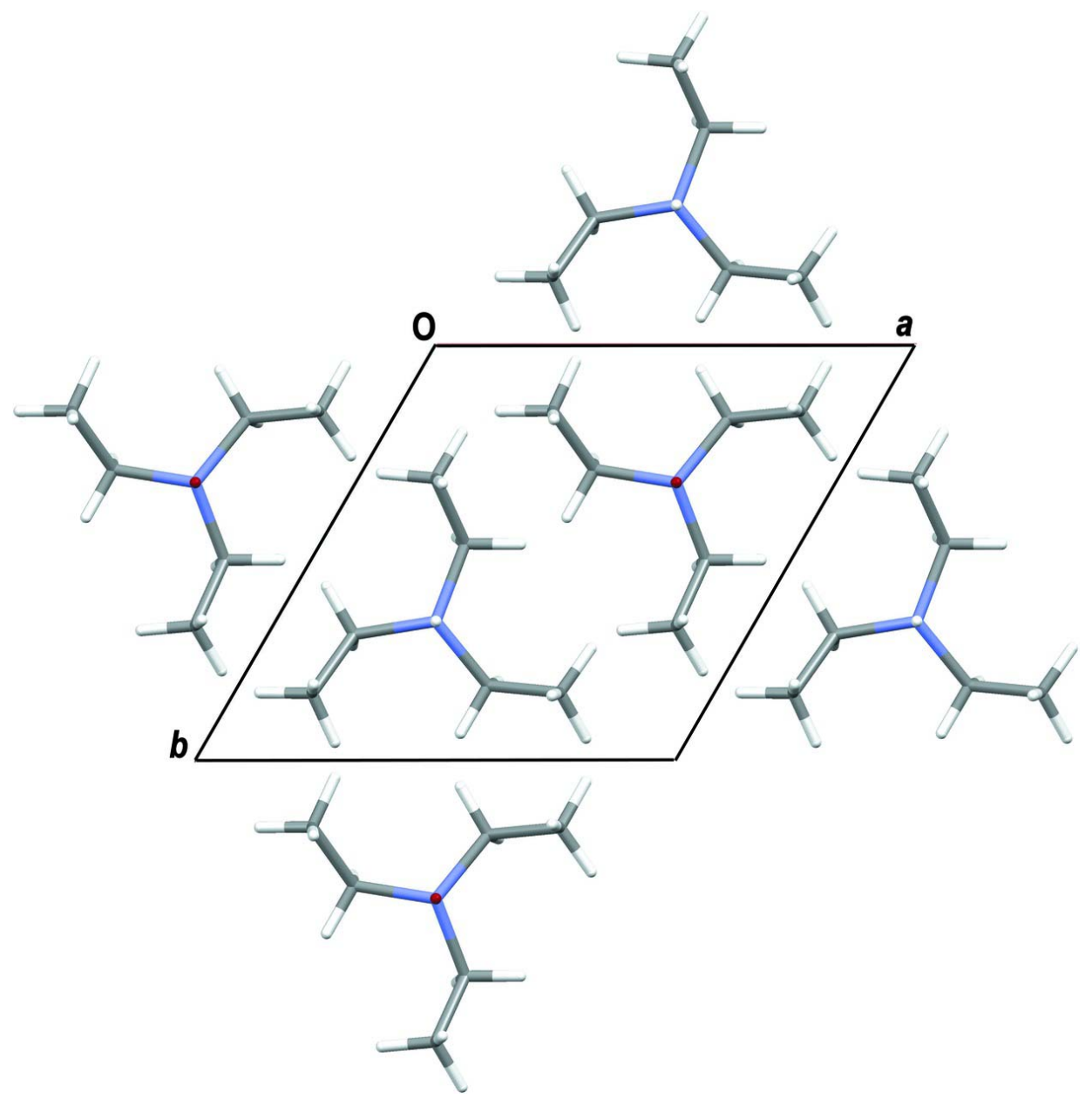

Figure 2

Packing diagram of (I) in the $a b$ plane.

\section{Triethylammonium bromide}

Crystal data

$\mathrm{C}_{6} \mathrm{H}_{16} \mathrm{~N}^{+} \cdot \mathrm{Br}$

$M_{r}=182.10$

Trigonal, $P 31 c$

Hall symbol: P $3-2 \mathrm{c}$

$a=8.3589$ (2) $\AA$

$c=7.3125(2) \AA$

$V=442.48(1) \AA^{3}$

$Z=2$

$F(000)=188$

Data collection

Bruker APEXII CCD area-detector diffractometer

Radiation source: fine-focus sealed tube Graphite monochromator $\varphi$ and $\omega$ scans
$D_{\mathrm{x}}=1.367 \mathrm{Mg} \mathrm{m}^{-3}$

Mo $K \alpha$ radiation, $\lambda=0.71073 \AA$

Cell parameters from 7729 reflections

$\theta=2.8-27.5^{\circ}$

$\mu=4.56 \mathrm{~mm}^{-1}$

$T=90 \mathrm{~K}$

Rod, colourless

$0.27 \times 0.11 \times 0.10 \mathrm{~mm}$

Absorption correction: multi-scan

$$
\text { (SADABS; Bruker, 2004) }
$$

$T_{\min }=0.450, T_{\max }=0.633$

8583 measured reflections

555 independent reflections

550 reflections with $I>2 \sigma(I)$ 
$R_{\text {int }}=0.026$

$\theta_{\max }=25.5^{\circ}, \theta_{\min }=4.0^{\circ}$

$h=-10 \rightarrow 10$

\section{Refinement}

Refinement on $F^{2}$

Least-squares matrix: full

$R\left[F^{2}>2 \sigma\left(F^{2}\right)\right]=0.020$

$w R\left(F^{2}\right)=0.058$

$S=1.24$

555 reflections

23 parameters

1 restraint

Primary atom site location: structure-invariant direct methods

Secondary atom site location: difference Fourier map

$$
\begin{aligned}
& k=-10 \rightarrow 10 \\
& l=-8 \rightarrow 8
\end{aligned}
$$

Hydrogen site location: inferred from neighbouring sites

$\mathrm{H}$-atom parameters constrained

$w=1 /\left[\sigma^{2}\left(F_{\mathrm{o}}^{2}\right)+(0.0371 P)^{2}+0.4873 P\right]$

where $P=\left(F_{\mathrm{o}}^{2}+2 F_{\mathrm{c}}^{2}\right) / 3$

$(\Delta / \sigma)_{\max }<0.001$

$\Delta \rho_{\max }=0.39 \mathrm{e} \AA^{-3}$

$\Delta \rho_{\min }=-0.39$ e $\AA^{-3}$

Absolute structure: Flack (1983), 273 Friedel pairs

Absolute structure parameter: $0.32(3)$

\section{Special details}

Geometry. All e.s.d.'s (except the e.s.d. in the dihedral angle between two 1.s. planes) are estimated using the full covariance matrix. The cell e.s.d.'s are taken into account individually in the estimation of e.s.d.'s in distances, angles and torsion angles; correlations between e.s.d.'s in cell parameters are only used when they are defined by crystal symmetry. An approximate (isotropic) treatment of cell e.s.d.'s is used for estimating e.s.d.'s involving 1.s. planes.

Refinement. Refinement of $F^{2}$ against ALL reflections. The weighted $R$-factor $w R$ and goodness of fit $S$ are based on $F^{2}$, conventional $R$-factors $R$ are based on $F$, with $F$ set to zero for negative $F^{2}$. The threshold expression of $F^{2}>\sigma\left(F^{2}\right)$ is used only for calculating $R$-factors(gt) etc. and is not relevant to the choice of reflections for refinement. $R$-factors based on $F^{2}$ are statistically about twice as large as those based on $F$, and $R$ - factors based on ALL data will be even larger. The crystal studied was an inversion twin with a 0.68 (3);0.32 (3) domain ratio.

Fractional atomic coordinates and isotropic or equivalent isotropic displacement parameters $\left(\AA^{2}\right)$

\begin{tabular}{lllll}
\hline & $x$ & $y$ & $z$ & $U_{\mathrm{iso}} * / U_{\mathrm{eq}}$ \\
\hline $\mathrm{C} 1$ & $0.1624(6)$ & $0.8395(6)$ & $0.4111(5)$ & $0.0323(9)$ \\
$\mathrm{H} 1 \mathrm{~A}$ & 0.1536 & 0.8181 & 0.2815 & $0.048^{*}$ \\
$\mathrm{H} 1 \mathrm{~B}$ & 0.2690 & 0.9571 & 0.4373 & $0.048^{*}$ \\
$\mathrm{H} 1 \mathrm{C}$ & 0.0533 & 0.8389 & 0.4534 & $0.048^{*}$ \\
$\mathrm{~N} 1$ & 0.3333 & 0.6667 & $0.4505(6)$ & $0.0168(12)$ \\
$\mathrm{H} 1$ & 0.3333 & 0.6667 & 0.3260 & $0.020^{*}$ \\
$\mathrm{C} 2$ & $0.1789(5)$ & $0.6982(5)$ & $0.5011(5)$ & $0.0232(7)$ \\
$\mathrm{H} 2 \mathrm{~A}$ & 0.0644 & 0.5830 & 0.4820 & $0.028^{*}$ \\
$\mathrm{H} 2 \mathrm{~B}$ & 0.1884 & 0.7240 & 0.6312 & $0.028^{*}$ \\
$\mathrm{Br} 1$ & 0.6667 & 0.3333 & 0.5017 & $0.01786(16)$ \\
\hline
\end{tabular}

Atomic displacement parameters $\left(\AA^{2}\right)$

\begin{tabular}{lllllll}
\hline & $U^{11}$ & $U^{22}$ & $U^{33}$ & $U^{12}$ & $U^{13}$ & $U^{23}$ \\
\hline $\mathrm{C} 1$ & $0.034(2)$ & $0.038(2)$ & $0.035(2)$ & $0.026(2)$ & $-0.0004(16)$ & $-0.0026(17)$ \\
$\mathrm{N} 1$ & $0.0162(14)$ & $0.0162(14)$ & $0.018(3)$ & $0.0081(7)$ & 0.000 & 0.000 \\
$\mathrm{C} 2$ & $0.0168(15)$ & $0.0228(14)$ & $0.0293(17)$ & $0.0095(12)$ & $0.0004(14)$ & $0.0001(16)$ \\
$\mathrm{Br} 1$ & $0.01867(19)$ & $0.01867(19)$ & $0.0162(2)$ & $0.00933(9)$ & 0.000 & 0.000 \\
\hline
\end{tabular}


Geometric parameters $\left(\AA,{ }^{\circ}\right)$

\begin{tabular}{llll}
\hline $\mathrm{C} 1-\mathrm{C} 2$ & $1.418(5)$ & $\mathrm{N} 1-\mathrm{C} 2^{\mathrm{i}}$ & $1.488(4)$ \\
$\mathrm{C} 1-\mathrm{H} 1 \mathrm{~A}$ & 0.9600 & $\mathrm{~N} 1-\mathrm{C} 2^{\mathrm{ii}}$ & $1.488(4)$ \\
$\mathrm{C} 1-\mathrm{H} 1 \mathrm{~B}$ & 0.9600 & $\mathrm{~N} 1-\mathrm{H} 1$ & 0.9100 \\
$\mathrm{C} 1-\mathrm{H} 1 \mathrm{C}$ & 0.9600 & $\mathrm{C} 2-\mathrm{H} 2 \mathrm{~A}$ & 0.9700 \\
$\mathrm{~N} 1-\mathrm{C} 2$ & $1.488(4)$ & $\mathrm{C} 2-\mathrm{H} 2 \mathrm{~B}$ & 104.4 \\
$\mathrm{C} 2-\mathrm{C} 1-\mathrm{H} 1 \mathrm{~A}$ & & $\mathrm{C} 2-\mathrm{N} 1-\mathrm{H} 1$ & 104.4 \\
$\mathrm{C} 2-\mathrm{C} 1-\mathrm{H} 1 \mathrm{~B}$ & 109.5 & $\mathrm{C} 2-\mathrm{N} 1-\mathrm{H} 1$ & 104.4 \\
$\mathrm{H} 1 \mathrm{~A}-\mathrm{C} 1-\mathrm{H} 1 \mathrm{~B}$ & 109.5 & $\mathrm{C} 22^{\mathrm{ii}}-\mathrm{N} 1-\mathrm{H} 1$ & $119.1(3)$ \\
$\mathrm{C} 2-\mathrm{C} 1-\mathrm{H} 1 \mathrm{C}$ & 109.5 & $\mathrm{C} 1-\mathrm{C} 2-\mathrm{N} 1$ & 107.5 \\
$\mathrm{H} 1 \mathrm{~A}-\mathrm{C} 1-\mathrm{H} 1 \mathrm{C}$ & 109.5 & $\mathrm{~N} 1-\mathrm{C} 2-\mathrm{C} 2-\mathrm{H} 2 \mathrm{~A}$ & 107.5 \\
$\mathrm{H} 1 \mathrm{~B}-\mathrm{C} 1-\mathrm{H} 1 \mathrm{C}$ & 109.5 & $\mathrm{C} 1-\mathrm{C} 2-\mathrm{H} 2 \mathrm{~B}$ & 107.5 \\
$\mathrm{C} 2-\mathrm{N} 1-\mathrm{C} 2 \mathrm{i}$ & 109.5 & $\mathrm{~N} 1-\mathrm{C} 2-\mathrm{H} 2 \mathrm{~B}$ & 107.5 \\
$\mathrm{C} 2-\mathrm{N} 1-\mathrm{C} 2^{\mathrm{ii}}$ & $114.03(18)$ & $\mathrm{H} 2 \mathrm{C}-\mathrm{C} 2-\mathrm{H} 2 \mathrm{~B}$ & 107.0 \\
$\mathrm{C} 2-\mathrm{N} 1-\mathrm{C}{ }^{\mathrm{i}}$ & $114.03(18)$ & & \\
\end{tabular}

Symmetry codes: (i) $-x+y,-x+1, z$; (ii) $-y+1, x-y+1, z$. 